\title{
GROWTH OF YOUNG JUNE SUCKER (CHASMISTES LIORUS) IS ASSOCIATED WITH ZOOPLANKTON DENSITY IN UTAH LAKE
}

\author{
Joshua D. Kreitzer ${ }^{1,2}$, Eric J. Billman ${ }^{1}$, Mark C. Belk¹, and Russell B. Rader ${ }^{1}$
}

\begin{abstract}
The endangered June sucker, Chasmistes liorus, is a long-lived, zooplanktivorous sucker endemic to Utah Lake, Utah. Habitat degradation both in the tributaries, where adults spawn, and in the lake has contributed to near complete mortality of larval and juvenile fish within the first few weeks after hatching, leading to a long-term lack of recruitment to the adult population. Recovery of June sucker depends on habitat restoration in the river and the lake that will increase the survival of young fish. Thus, it is important to understand how habitat heterogeneity within the lake will influence the survival and growth of young June suckers. To this end, we compared the survival and growth of juvenile June suckers at 2 spatial scales: (1) large regions across the lake and (2) habitats within regions, namely, open water versus vegetated habitats. We related patterns of survival and growth to food availability (zooplankton density). Growth, but not survival, differed significantly among sites at the landscape scale. Sites with higher zooplankton density had higher mean growth. At the habitat scale, survival was greater in vegetated habitats, whereas growth was higher in the open water. Again, increased growth occurred in the area where zooplankton density was greatest. The density of small zooplankton (e.g., Brachionus rotifers) is a good indicator of habitat suitability for young June suckers at both the regional scale and the habitat scale. Future restoration activities should focus on submersed macrophytes and the spawning tributaries (e.g., Hobble Creek) that transport larval fish into the most productive regions of Utah Lake with the highest zooplankton densities (e.g., Provo Bay).
\end{abstract}

Resumen.-La especie en peligro Chamistes liorus es una especie de pez longeva zooplanctívora de la familia Catostomidae endémica del Lago Utah, en el estado de Utah, Estados Unidos. La degradación del hábitat tanto de los ríos afluentes donde desovan los adultos como del lago ha contribuido a la casi absoluta mortalidad de las larvas y jóvenes dentro de las primeras pocas semanas después de eclosionar, llevando a largo plazo a la falta de reclutamiento de la población adulta. La recuperación de Chamistes liorus depende de la restauración del hábitat en el río y en el lago lo cual aumentará la supervivencia de los jóvenes. Para brindar información al esfuerzo por esta restauración es importante entender la forma en la que la supervivencia y el crecimiento de los jóvenes de Chamistes liorus se ven influenciados por la variación en los hábitats encontrados en el lago. Con este objetivo, comparamos la supervivencia y el crecimiento de jóvenes de Chamistes liorus entre hábitats en dos escalas espaciales (escala de paisaje y escala de hábitat). Determinamos la relación entre los patrones de supervivencia y crecimiento con la disponibilidad de alimento (densidad del zooplancton). A la escala de paisaje, el crecimiento, aunque no la supervivencia, difirió significativamente entre sitios. Los sitios con mayor densidad de zooplancton tuvieron un crecimiento promedio mayor. A la escala de hábitat, la supervivencia fue más elevada en el hábitat con vegetación, mientras que el crecimiento fue mayor en aguas abiertas. Nuevamente, hubo un aumento en el crecimiento en el área en donde la densidad del zooplancton fue más alta. La densidad del zooplancton y la composición de las especies son un buen indicador de la calidad del hábitat para jóvenes de Chamistes liorus tanto a la escala de paisaje como a la de hábitat. Las actividades para restaurar el hábitat en el futuro deben enfocarse en asegurar las conexiones entre los ríos afluentes que se usan para desovar y las áreas del lago con mayor densidad de zooplancton.

The June sucker, Chasmistes liorus, is an endangered, zooplanktivorous fish endemic to Utah Lake and its tributaries (USFWS 1986, 1999). Utah Lake is a large, shallow eutrophic lake at the eastern edge of the Great Basin physiographic province (Utah; Fuhriman et al. 1981). Naturally spawned juvenile suckers have been unable to recruit to the breeding population, in part due to habitat degradation in the spawning tributaries. Low discharge in the spawning tributaries appears to cause complete larval mortality before the larvae can return to the lake (USFWS 1999, Ellsworth et al. 2010). Consequently, thousands of age-1 suckers raised from brood stock and maintained in a hatchery are transported to Utah Lake each year (Andersen et al. 2007, Rasmussen et al. 2009). However, complete recovery will require habitat restoration in both the spawning tributaries and the lake to allow for natural recruitment to the

${ }^{1}$ Department of Biology, Brigham Young University, 401 WIDB, Provo, UT 84602

${ }_{2}^{2}$ Present address: 110 MGB, Old Dominion University, Norfolk, VA 23529. E-mail: joshkreitzer@gmail.com 


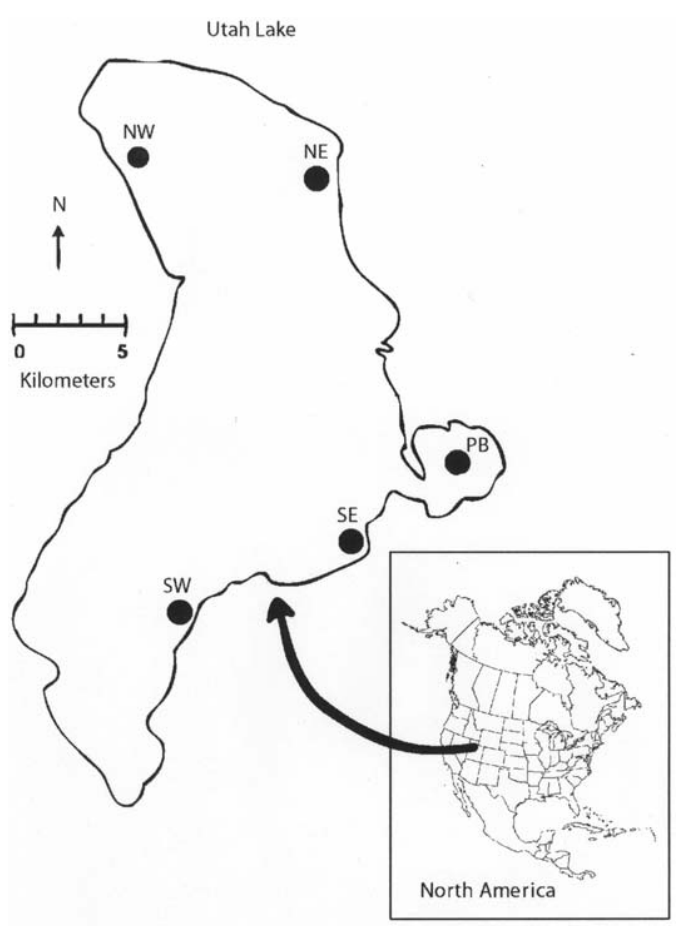

Fig. 1. A map of Utah Lake showing the regional locations (solid black circles) and its position within the United States. $\mathrm{NE}=$ northeast main lake, $\mathrm{NW}=$ northwest main lake, $\mathrm{PB}=$ Provo Bay, $\mathrm{SE}=$ southeast main lake, $\mathrm{SW}=$ southwest main lake.

breeding population (Rader et al. 2010). For successful recruitment, young fish need access to habitats with appropriate temperatures and food as they transition from larvae to juveniles; such factors can be affected by the presence of aquatic macrophytes in the lake environment (e.g., Ellsworth et al. 2010, Rader et al. 2010).

Resource availability is often scale-dependent, so it is usually necessary to study the effects of resource availability at multiple spatial scales (Wiens et al. 1986, Wiens 1989, Werner 1998). Large landscape regions within the lake and habitats within those regions may be valuable to the growth and survival of juvenile June sucker. We divided Utah Lake into 5 regions, consisting of Provo Bay and 4 additional regions in the main body of the lake. Provo Bay is a large, shallow extension of the lake (depth < $1.5 \mathrm{~m}$ ) with a reduced fetch and abundant emergent macrophytes. The habitat scale refers to patches of open water and emergent macrophyte beds (reeds Phragmites australis, bulrushes Scirpus acutus, and cattails Typha latifolia) nested within Provo Bay. These 2 habitat types are known to differ in physicochemical properties (e.g., light penetration and structural complexity; Brotherson 1981, Joniak et al. 2007) that affect the survival and growth of fishes (Jeffres et al. 2008).

Understanding the habitat requirements of juvenile June sucker at multiple scales will be critical to guiding restoration efforts. We quantified differences in the growth and survival of young June sucker among each of the 5 regions and between habitat patches within Provo Bay (open water versus emergent macrophytes) to determine how variation at both scales may influence rates of natural recruitment. We also compared these patterns of growth and survival with variation in the abundance of zooplankton at both scales.

\section{Methods}

\section{Regional Effects}

We measured the growth and survival of juvenile June sucker in 4 replicate cages placed in each of the 5 regions on 8 and 9 July 2008 (Fig. 1). These 5 regions vary in physicochemical properties that may produce differences in zooplankton abundance (Table 1). Our cages were modified after Billman and Belk (2009) and consisted of rectangular frames $(3 \times 2 \times$ $1 \mathrm{~m})$ constructed from PVC pipe $(2.54 \mathrm{~cm}$ in diameter) and covered with vinyl-coated polyester screening (1.5-mm mesh) on the sides and bottom. The mesh size prevented fish from escaping but did not constitute a barrier to the movement of zooplankton. The top of each cage was covered with netting (4-cm mesh) to deter predation by birds and mammals.

Six hundred juvenile June suckers obtained from the Utah Division of Wildlife Resources' (UDWR) Fisheries Experiment Station (FES) in Logan, Utah, were placed in each cage on 21-23 July. These fish were 6 weeks old, and although they were derived from multiple families, all families were combined in each cage. Larval June suckers were fed brine shrimp nauplii in the hatchery for the first 4 weeks of life and then were transitioned to a dry formula prepared especially for young June sucker (Doug Routledge, UDWR, personal communication). Four groups of 25 fish each were digitally photographed in shallow trays containing a ruler. Average standard length (SL) was $15.13 \mathrm{~mm}(\mathrm{SE}=0.18, n=100)$. 
TABLE 1. The location and physicochemical differences among 5 regions in Utah Lake and between habitats (open water and emergent vegetation) in Provo Bay.

\begin{tabular}{llcl}
\hline Site & Location & Depth $(\mathrm{m})$ & Substrate \\
\hline Northeast & $40^{\circ} 18.718^{\prime} \mathrm{N}, 111^{\circ} 45.937^{\prime} \mathrm{W}$ & 1.29 & sand \\
Northwest & $40^{\circ} 18.940^{\prime} \mathrm{N}, 111^{\circ} 53.160^{\prime} \mathrm{W}$ & 2.11 & rock and silt \\
Provo Bay & $40^{\circ} 11.686^{\prime} \mathrm{N}, 111^{\circ} 41.909^{\prime} \mathrm{W}$ & 1.16 & fine sediment $(10-40 \mathrm{~cm})$ \\
Southeast & $40^{\circ} 09.760^{\prime} \mathrm{N}, 111^{\circ} 45.135^{\prime} \mathrm{W}$ & 1.77 & sand \\
Southwest & $40^{\circ} 07.134^{\prime} \mathrm{N}, 111^{\circ} 50.837^{\prime} \mathrm{W}$ & 1.73 & rock \\
Open & $40^{\circ} 11.454^{\prime} \mathrm{N}, 111^{\circ} 40.109^{\prime} \mathrm{W}$ & 0.66 & fine sediment \\
Vegetated & $40^{\circ} 11.385^{\prime} \mathrm{N}, 111^{\circ} 39.994^{\prime} \mathrm{W}$ & 0.52 & fine sediment \\
\hline
\end{tabular}

At the end of 5 weeks (25-27 August), all fish were removed from the cages and counted to calculate survival. A few cages were excluded from the survival analysis because damage to the cages had probably allowed some fish to escape. The final average SL was calculated for each cage based on a randomly selected subsample of at least 50 fish by using the computer program tpsDig2 (Rohlf 2008). As before, fish were digitally photographed in groups of 25 individuals. For each cage, the initial mean standard length was subtracted from the final mean standard length to determine growth. Under authorization of the UDWR, all fish were released into Utah Lake at the conclusion of the study.

\section{Habitat Effects}

The habitat experiment was conducted over an 8-week period between July and September (2003) about $3 \mathrm{~km}$ east of the Provo Bay regional site (Fig. 1). Twenty-five June suckers were added to 4 replicate cages in each habitat type (open water and emergent macrophytes). These cages were similar to those used at the regional scale, except they were smaller $(0.5 \times$ $1.0 \times 1.0 \mathrm{~m}$ ) and fixed to the substrate (Belk et al. 2008, Kreitzer et al. 2010). Both survival and growth were calculated as described in the regional experiment.

\section{Resource Availability}

Although we compared the total zooplankton density among sites, we also analyzed differences in the densities of Brachionus rotifers and cyclopoid copepods because they are known to be important in the diet of young June sucker (Kreitzer et al. 2010). Zooplankton samples were collected near to but outside of the cages at each of the 5 regional sites and at both habitat sites. Previous research using the same cage mesh as this study has shown no difference between the density of zooplankton needed by June suckers inside cages and the density needed outside cages (Gonzalez 2004). Three replicate samples were collected at each site 3 times on weeks one, three, and five of the regional experiment and on weeks one, three, and six of the habitat experiment, for a total of 9 samples per site. Zooplankton were collected by lowering a 20 -cm-diameter plankton net $(64-\mu \mathrm{m}$ mesh) to the bottom of the lake, allowing the water to settle, moving the net $30 \mathrm{~cm}$ to the side, and pulling it to the surface (sensu Kreitzer et al. 2010).

Each sample was stored in 70\% ethyl alcohol prior to enumeration and identification of zooplankton. We performed a power analysis to determine the number of subsamples needed to accurately estimate densities for each taxa (Elliott 1977). All samples were rinsed through a $63-\mu \mathrm{m}$ mesh into a $140-\mathrm{mL}$ beaker, and subsamples were extracted from a homogenous mixture with a $1-\mathrm{mL}$ Stempel pipette. The mean number of zooplankton per subsample was multiplied by 140 and divided by the cubic meters sampled (mean depth of water column $\times$ area of the net opening) to determine densities per cubic meter.

\section{Statistical Analyses}

Survival, growth, and zooplankton were compared among regional sites using ANOVA and Tukey-Kramer pairwise mean comparisons implemented in NCSS (Hintze 2008). Survival, growth, and zooplankton were compared between habitat types using the 2-sample $t$ test $(\alpha=0.05)$, also implemented in NCSS (Hintze 2008). Both data sets were logit-transformed to meet parametric assumptions of normality and equal variances.

\section{REsults}

\section{Regional Effects}

Average survival ranged from $78.1 \%$ (SD $=$ $6.6 \%)$ in Provo Bay to $63.8 \%(\mathrm{SD}=4.5 \%)$ at the 


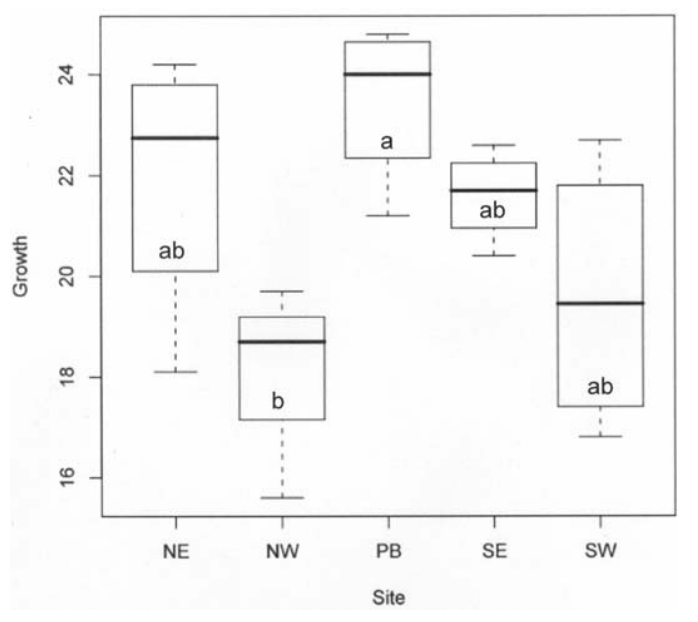

Fig. 2. Box plots showing the mean growth (mm SL) of juvenile June sucker reared in cages for 5 weeks in 5 regions of Utah Lake. Site descriptions and locations are provided in Table 1 and Figure 1. Significant differences between means are indicated with different letters.

northeast site, with the remaining sites showing intermediate levels of survival: southwest $=75 \%$ $(\mathrm{SD}=0.9 \%)$, southeast $=66.9 \%(\mathrm{SD}=15.6 \%)$, and northwest $=66.2 \%(\mathrm{SD}=4.2 \%)$. However, none of these differences in survival were statistically significant $\left(F_{4,10}=1.27, P=0.344\right)$. Although growth rates were generally greater in Provo Bay (Fig. 2), the only significant differences occurred between Provo Bay (23.5 $\mathrm{mm} / 5$ weeks, $\mathrm{SD}=1.6$ ) and the northwest site $(18.2 \mathrm{~mm} / 5$ weeks, SD $=1.7)$.

Total zooplankton density differed among sites on weeks one $\left(F_{4,9}=36.16, P<0.001\right)$, three $\left(F_{4,10}=16.56, P<0.001\right)$, and five $\left(F_{4,10}\right.$ $=18.06, P<0.001)$. That is, Provo Bay had significantly greater total zooplankton density than the other sites on weeks one and five, whereas both Provo Bay and the northeast site showed significantly greater densities on week three (Fig. 3a). These differences in total zooplankton were largely attributed to a greater density of Brachionus rotifers and cyclopoid copepods in Provo Bay. That is, the density of Brachionus sp. was greater in Provo Bay relative to the other sites (Fig. 3b) on all 3 weeks (week one: $F_{49}=124.33, P<0.001$; week three: $F_{4,10} \stackrel{=}{=} 38.31, P<0.001$; week five: $\left.F_{4,10}=8.16, P=0.003\right)$. Similarly, the density of cyclopoid copepods was also greater in Provo Bay on all three weeks (week one: $F_{4,10}$ $=8.55, P=0.003$; week three: $F_{4,10}=27.56$,
$P<0.001$; week five: $\left.F_{4,10}=43.73, P<0.001\right)$ except for the northeast site (Fig. 3c). Cyclopoid copepods did not differ between Provo Bay and the northeast site on weeks one and three.

\section{Habitat Effects}

Survival was significantly greater in vegetated sites $(90 \%, \mathrm{SD}=9.1 \%)$ than in open $(70 \%$, $\mathrm{SD}=11.5 \%)$ sites (2-tailed $t$ test: $P=0.05)$, whereas growth showed the opposite pattern, and was significantly greater (2-tailed $t$ test: $P=0.002)$ in the open water $(\mathrm{SL}=38.9 \mathrm{~mm}$, $\mathrm{SD}=1.06)$ than in vegetated habitats $(\mathrm{SL}=$ $31.9 \mathrm{~mm}, \mathrm{SD}=1.33$ ).

Although total zooplankton density did not differ between sites on weeks one (2-tailed $t$ test: $P=0.539)$ and three (2-tailed $t$ test: $P=$ $0.189)$, densities were greater in the open water on week six (2-tailed $t$ test: $P=0.031$; Fig. $4 \mathrm{a}$ ). Brachionus rotifers did not differ between sites on weeks one (2-tailed $t$ test: $P=0.231)$ or three (2-tailed $t$ test: $P=0.332$ ) but were also greater in the open on week six (2-tailed $t$ test: $P=0.033$; Fig. 4b). However, cyclopoid copepod density did not differ between sites on any of the weeks (week one, 2-tailed $t$-test: $P=$ 0.607; week three, 2-tailed $t$ test: $P=0.097$; week six, 2-tailed $t$ test: $P=0.159)$.

\section{Discussion}

Previous work has shown that young June suckers rely on a diet high in both Brachionus rotifers and cyclopoid copepods (Kreitzer et al. 2010). Our results suggest that zooplankton abundance, particularly Brachionus rotifers and cyclopoid copepods, may serve as metrics for assessing site suitability for stocking young June sucker and for assessing the effectiveness of habitat restoration. At a regional scale, generally faster growth rates of juvenile June sucker corresponded with greater zooplankton densities in Provo Bay and, to a lesser extent, in the northeast region. Similarly, faster growth rates at the habitat scale corresponded with greater zooplankton densities, especially Brachionus rotifers, in the open water within Provo Bay. Although the survival of juvenile June sucker was highest in Provo Bay, this trend was not statistically significant, probably because of a reduction in statistical power attributed to damaged cages. However, increased growth rates due to higher zooplankton densities in Provo Bay would decrease the time that fish are 

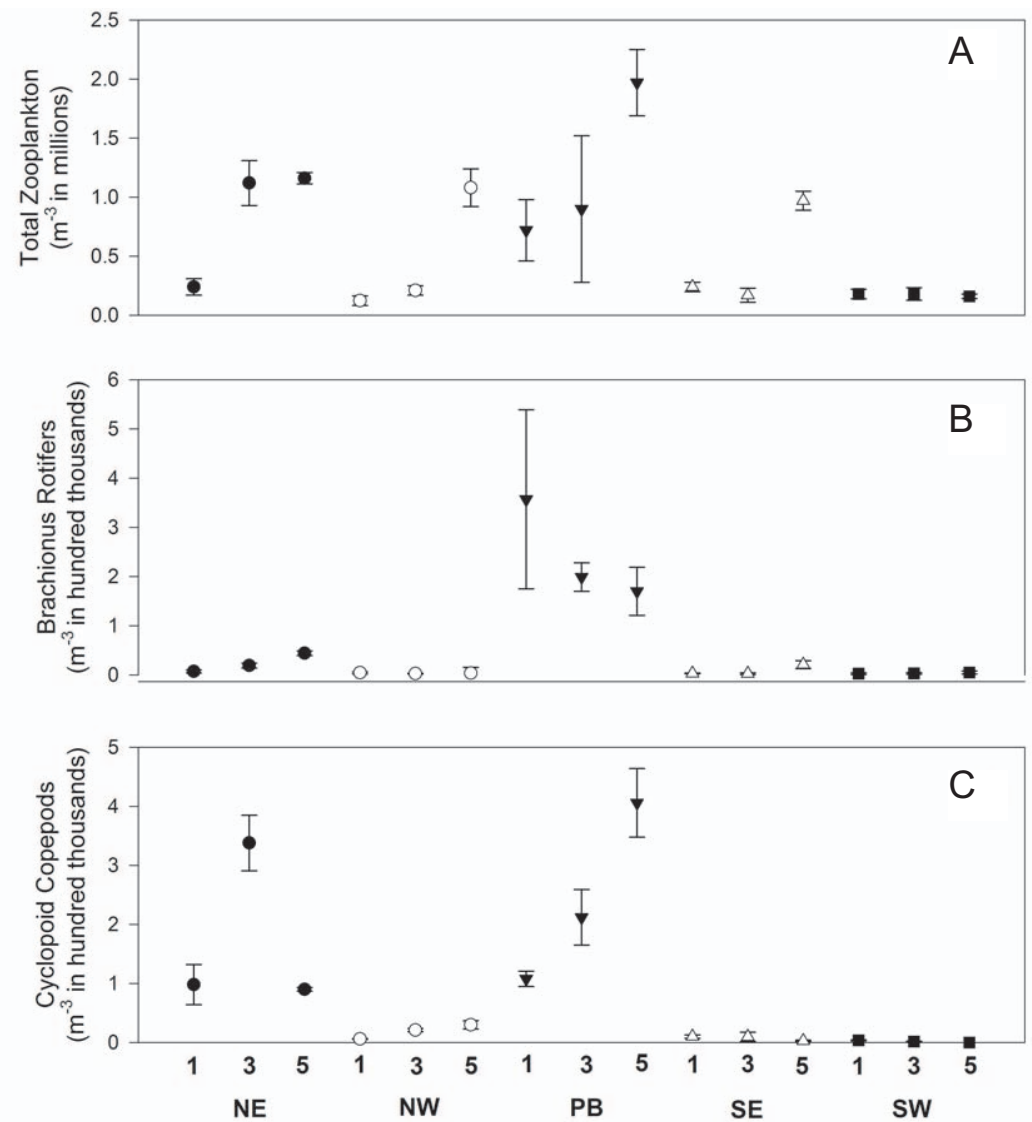

Fig. 3. Average densities of zooplankton in 5 regions of Utah Lake: A, total zooplankton; B, Brachionus rotifers; $\mathrm{C}$, cyclopoid copepods. Data are shown in 3 columns for each region, representing weeks one, three, and five of the caging experiment (2008). Errors bars represent one standard error around the mean.

vulnerable to predation (Friedland et al. 2000, Islam et al. 2010), and these growth rates should thus have a significant positive effect on longterm survival under natural conditions.

Our data indicate that Provo Bay is the best region in Utah Lake for the growth and survival of juvenile June suckers. This observation has important implications for the restoration of this species because only one of the 6 tributaries that drain into Utah Lake flows directly into Provo Bay (Hobble Creek). Connectivity of larval and juvenile June suckers between regions within the lake is unknown but potentially restricted because of the limited swimming abilities of these small fish. If the movement of juvenile fish among regions of the lake is limited, then Hobble Creek is the only spawning tributary that transports larval June suckers directly into the most productive region (Provo Bay) with the greatest growth and possibly the greatest survival rates. Thus, restoration of this species may be critically affected by the successful restoration of Hobble Creek as a spawning tributary for adult June suckers.

At the habitat scale within Provo Bay, survival of juvenile June suckers was greatest in the vegetated habitat, whereas food availability and growth was greatest in open waters. Mortality of juvenile June suckers is strongly affected by predation from a variety of fish predators introduced to Utah Lake over the past 100 years, such as white bass, Morone chrysops (Thomas and Crowl 1997, Belk et al. 2001, Kovalenko et al. 2010). Aquatic macrophytes are known to provide a refuge for small fish from predation by larger fish (e.g., Mittelbach 1986). Young June suckers require access to open water for food and access to vegetation for shelter and refuge if they are to maximize their growth and minimize mortality, respectively. Patches of 

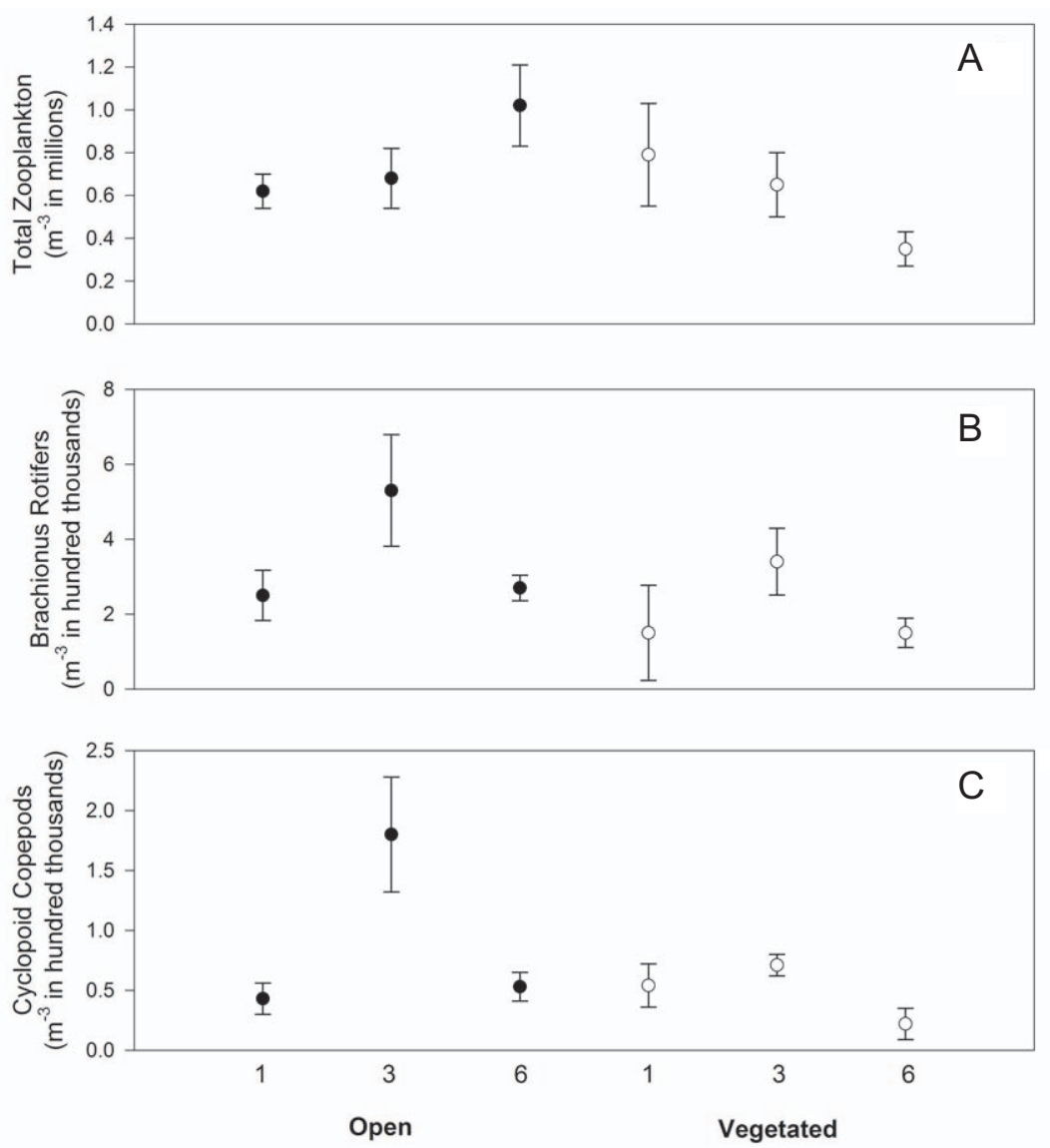

Fig. 4. Average densities of zooplankton between habitat types (open water versus vegetated): A, total zooplankton; B, Brachionus rotifers; C, cyclopoid copepods. Data are shown in 3 columns for each habitat type representing, weeks one, three, and six of the caging experiment in Provo Bay (2008). Error bars represent one standard error around the mean.

submersed aquatic macrophytes (e.g., Potamogeton spp.) located in the open water of Provo Bay may be ideal for the growth and survival of larval and juvenile June suckers because they can provide shelter from predation with easy access to abundant food (see Ferrer-Montano and Dibble 2002 for another example). Patches of submersed vegetation may have been common in Provo Bay before the introduction of common carp (Cyprinus carpio) to Utah Lake. Carp are known to consume and destroy submersed vegetation in lakes around the world (e.g., Crivelli 1983). We suggest that restoration of June suckers would benefit from the removal of carp and the restoration of submersed macrophytes in Provo Bay. However, larval June suckers must first find their way to zooplankton-rich open water habitats through dense stands of emergent vegetation.
Such stands of emergent vegetation, especially Phragmites australis and Typha latifolia, surround the outflow of spawning tributaries, likely creating a barrier to open water habitats for young June suckers. Restoration efforts should include plans to reduce this barrier and give juvenile June suckers greater access to open water habitats with patches of submersed vegetation.

In summary, we suggest that the restoration of endangered June suckers endemic to Utah Lake should include (1) restoration of Hobble Creek as a spawning tributary to Provo Bay, (2) reduction of carp in Provo Bay, (3) restoration of submersed macrophytes in Provo Bay, and (4) a reduction of emergent macrophyte barriers surrounding the mouth of the spawning tributaries. Although these steps involve significant challenges (especially the removal of 
carp), restoring a naturally reproducing population and lifting June sucker from the federal endangered list is a worthy goal. These steps involving the entire stream-lake ecosystem should be applicable to the restoration of other threatened potamodromous fish in the western United States and elsewhere around the globe.

\section{ACKNOWLEDGMENTS}

Funding for the experiments was provided by the Central Utah Water Conservancy District, the Utah Division of Wildlife Resources (UDWR), and the Department of Biology at Brigham Young University (BYU). UDWR personnel provided field assistance. Field and laboratory assistance was provided by numerous graduate and undergraduate students at BYU. Dr. Dennis Shiozawa provided many helpful comments and suggestions. This research was approved by the Institutional Animal Care and Use Committee at Brigham Young University.

\section{Literature Cited}

Andersen, M.E., C.J. Keleher, J.E. Rasmussen, E.S. HanSEN, P.D. Thompson, D.W. Speas, M.D. RoutLedge, AND T.N. HEDRICK. 2007. Status of June sucker in Utah Lake and refuges. Pages 39-58 in M.J. Brouder and J.A. Scheurer, editors, American Fisheries Society Symposium. American Fisheries Society.

Belk, M.C., L.J. Benson, J. Rasmussen, and S.L. Peck. 2008. Hatchery-induced morphological variation in an endangered fish: a challenge for hatchery-based recovery efforts. Canadian Journal of Fisheries and Aquatic Sciences 65:401-408.

Belk, M.C., M.J. Whitney, and G.B. Schaalje. 2001. Complex effects of predators: determining vulnerability of the endangered June sucker to an introduced predator. Animal Conservation 4:251-256.

Billman, E.J., AND M.C. BELK. 2009. Growth and survival of juvenile June sucker in enclosures in Utah Lake: feasibility of modified cage culture for an endangered species. North American Journal of Aquaculture 71: 281-286.

Brotherson, J.D. 1981. Aquatic and semiaquatic vegetation of Utah Lake and its bays. Great Basin Naturalist Memoirs 5:68-84.

Crivelui, A.J. 1983. The destruction of aquatic vegetation by carp: a comparison between southern France and the United States. Hydrobiologia 106:37-41.

ELLIOTT, J.M. 1977. Some methods for the statistical analysis of samples of benthic invertebrates. 2nd edition. Freshwater Biological Association.

Ellsworth, C.M., M.C. Belk, and C.J. Keleher. 2010 Residence time and drift patterns of larval June sucker Chasmistes liorus in the lower Provo River as determined by otolith microstructure. Journal of Fish Biology 77:526-537.

Ferrer-Montano, O.J., AND E.D. Dibble. 2002. Aquatic plant densities and larval fish abundance in vegetated habitats on the Tennessee-Tombigbee Waterway system. Journal of Freshwater Ecology 17:455-460.

Friedland, K.D., L.P. Hansen, D.A. Dunkley, and J.C. MACLEAN. 2000. Linkage between ocean climate, post-smolt growth, and survival of Atlantic salmon (Salmo salar L.) in the North Sea area. Ices Journal of Marine Science 57:419-429.

Fuhriman, D.K., L.B. Merritt, A.W. Miller, and H.S. Sтоск. 1981. Hydrology and water quality of Utah Lake. Great Basin Naturalist Memoirs 5:43-67.

GonZaLEZ, D.B. 2004. Density effects on growth, survival and diet of June sucker (Chasmistes liorus): a component Allee effect in an endangered species. Master's thesis, Brigham Young University, Provo, UT.

HiNTZE, J. 2008. NCSS 2007. NCSS, LLC, Kaysville, UT

IsLam, M.S., M. UENO, AND Y. Yamashita. 2010. Growthdependent survival mechanisms during the early life of a temperate seabass (Lateolabrax japonicus): field test of the 'growth-mortality' hypothesis. Fisheries Oceanography 19:230-242.

Jeffres, C.A., J.J. Opperman, and P.B. Moyle. 2008. Ephemeral floodplain habitats provide best growth conditions for juvenile Chinook salmon in a California river. Environmental Biology of Fishes 83:449-458.

Joniak, T., N. KucZyŃSKa-KipPEn, and B. Nagengast. 2007. The role of aquatic macrophytes in microhabitatual transformation of physical-chemical features of small water bodies. Pages 101-109 in R.D. Gulati, E. Lammens, N. Pauw, and E. Donk, editors, Shallow lakes in a changing world. Springer, Netherlands.

Kovalenko, K.E., E.D. Dibble, A.A. Agostinho, G. CanTanhede, AND R. Fugi. 2010. Direct and indirect effects of an introduced piscivore, Cichla kelberi and their modification by aquatic plants. Hydrobiologia 638:245-253.

Kreitzer, J.D., M.C. BelK, D.B. Gonzalez, R.C. TuckField, D.K. Shiozawa, and J.E. Rasmussen. 2010. Ontogenetic diet shift in the June sucker Chasmistes liorus (Cypriniformes, Catostomidae) in the early juvenile stage. Ecology of Freshwater Fish 19:433-438.

MitTelbach, G.G. 1986. Predator-mediated habitat use: some consequences for species interactions. Environmental Biology of Fishes 16:159-169.

Rader, R.B., M.C. Belk, R. Hotchiss, and J. Brown. 2010. The stream-lake ecotone: potential habitat for juvenile endangered June suckers (Chasmistes liorus). Western North American Naturalist 70:553-561.

Rasmussen, J.E., M.C. Belk, and S.L. Peck. 2009. Endangered species augmentation: a case study of alternative rearing methods. Endangered Species Research 8:225-232.

RoHLF, FJ. 2008. tpsDig2, digitize landmarks and outlines. Version 2.12.

Thomas, H.M., AND T.A. CRowL. 1997. Effects of structural complexity on predator-prey interactions between introduced white bass and endangered June suckers. Bulletin of the Ecological Society of America 78:195.

[USFWS] U.S. Fish and Wildifife Service. 1986. Endangered and threatened wildlife and plants; final rule determining the June sucker (Chasmistes liorus) to be an endangered species with critical habitat. Federal Register 51:10851-10857.

1999. June Sucker (Chasmistes liorus) Recovery Plan. Denver, CO.

WERnER, E.E. 1998. Ecological experiments and a research program in community ecology. In: W.J. Resetarits Jr. 
and J. Bernardo, editors, Experimental ecology: issues and perspectives. Oxford University Press, New York, NY.

WIENS, J.A. 1989. Spatial scaling in ecology. Functional Ecology 3:385-397.

Wiens, J.A., J.F. AdDicotT, T.J. CASE, AND J. Diamond. 1986. Overview: the importance of spatial and temporal scale in ecological investigations. In: J. Diamond and T.J. Case, editors, Community ecology. Harper and Row, New York, NY

Received 7 October 2011 Accepted 1 November 2011 